\title{
syn-Diastereoselective glycolate aldol addition reactions of
}

\section{$\mathbf{N}_{3}$-(p-methoxyphenoxy)acetyloxazolidine-2-thiones}

Craig Haynes, Cassie A. Goodman, Juandah Bruce, Sarah C. Genin,

Brad J. Austermuehle, Victor L. Leong, Austin R. Leise, Robert Larson,

Christopher G. Hamaker and Shawn R. Hitchcock*

Department of Chemistry, Illinois State University, Normal, IL 61790-4160
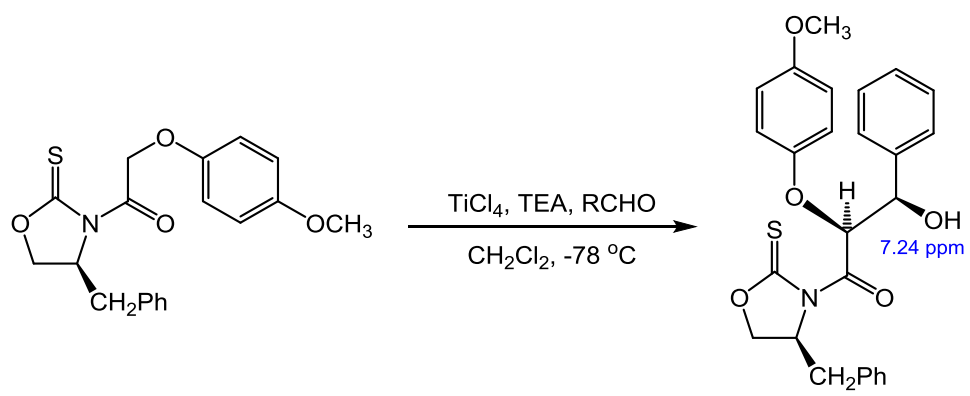

Abstract-An $\quad N_{3}$-(p-methoxyphenoxy)acetyloxazolidine-2-thione has been synthesized and employed in the glycolate asymmetric aldol addition reaction with aromatic and aliphatic aldehydes. The observed diastereoselectivies ranged from 62:38 to 80:20 when the reaction was conducted at $-25{ }^{\circ} \mathrm{C}$. The diastereoselectivities improved to $75: 25$ to $94: 6$ when the reaction was conducted at $-78{ }^{\circ} \mathrm{C}$. The absolute stereochemistry of the aldol adducts was determined by ${ }^{1} \mathrm{H}$ NMR spectroscopy and X-ray crystallography. The ${ }^{1} \mathrm{H}$ NMR spectra of the aldol adducts contained a signal (the $\alpha$-proton of the glycolate position of the aldol sidechain) that was highly deshielded. 


\section{Introduction}

The chiral auxiliary guided asymmetric glycolate aldol addition reaction has been proven to be a versatile reaction that has allowed for the synthesis of a diverse array of natural products. ${ }^{1-3}$ The seminal efforts of Evans $^{1 \mathrm{a}}$ and coworkers in this area employed an $\mathrm{N}_{3}-p-$ methoxybenzyloxyacetyl-oxazolidin-2-one auxiliary (1) in the synthesis of the polyether antibiotic X-206 (Chart 1). ${ }^{1 \text { a }}$ This work would be followed by the works of Crimmins and Choy, ${ }^{2}$ Hulme and Rosser, ${ }^{3}$ Davies and coworkers, ${ }^{4}$ and Roush Owens. ${ }^{5}$ and others. Seeberger and coworkers extended this work by the use of the more labile para-methoxybenzyl glycolate group. ${ }^{6}$ Crimmins and coworkers later employed oxazolidine-2-thiones as effective chiral auxiliaries for the aldol addition reaction ${ }^{7 \mathrm{a}-\mathrm{d}}$ and the glycolate aldol reactions. ${ }^{7 \mathrm{e}-\mathrm{h}}$ Romea, Urpí and coworkers ${ }^{8}$ developed highly stereoselective anti-aldol addition using a thiazolidine-2-thione system. These glycolate systems have all been used to great success as well as other chiral auxiliary systems. ${ }^{9-12}$

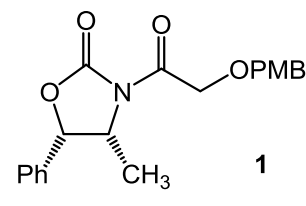

Evans, $1989^{1 a}$

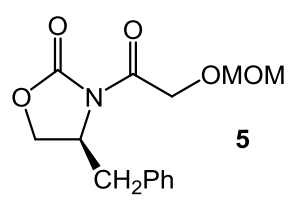

Roush and Owen, $2005^{5}$

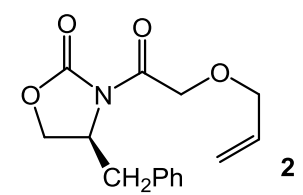

Crimmins and Choy, $1997^{2}$

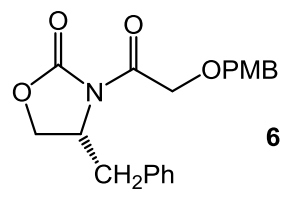

Seeberger et al., $2008^{6}$

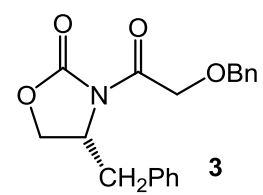

Hulme and Rosser, $2002^{3}$

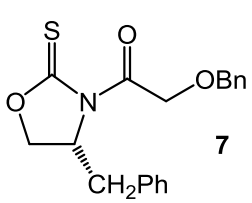

Crimmins et al., $2008^{7}$

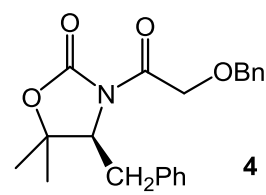

Davies et al., $2004^{4}$

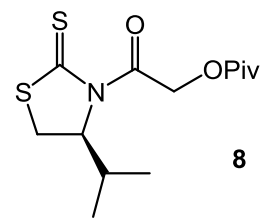

Romea, Urpi, et al., $2012^{8}$ 
Chart 1. Oxazolidinone, oxazolidine-2-thione, and thiazolidine-2-thione glycolates.

A key component of interest is the glycolate protecting group. The benzyl group and the related $p$-methoxybenzyl group are the most commonly used (see Chart 1 references). The most commonly used protecting groups for the hydroxyl group in the glycolate series are the benzyl group and its derivatives; these protecting groups are ubiquitous in natural product synthesis. ${ }^{14}$ In contrast, the $p$-methoxyphenoxy group is a protecting group that has not been applied as often. It has the utility that it is a robust protecting group that can be orthogonally removed in the presence of a myriad of functional groups. ${ }^{15}$ We had previously used this protecting group in glycolate aldol addition reactions with Ephedra based oxadiazinones. ${ }^{16}$ Based on this work, we became interested in determining if the p-methoxy- phenoxy group would be useful in the Crimmins' based oxazolidine-2-thione based glycolate system. It is in this context that this work in the application of an $\mathrm{N}_{3}-p$-methoxyphenoxyacetyl- oxazolidinone in the asymmetric glycolate aldol addition reaction, and the observation of a highly deshielded $\alpha$-proton of the glycolate system is described.

\section{Results and discussion}

The oxazolidine-2-thione auxiliary (10) was prepared as described by Crimmins and coworkers by reacting $(S)$-phenylalanine with thiophosgene in dichloromethane in the presence of triethylamine. ${ }^{17 a}$ This process was carried out on 15-gram scale and the product was purified by flash chromatography. This compound was then treated with $p$-methoxyphenoxyacetic acid 
by reaction with EDC and catalytic $\mathrm{DMAP}^{17 \mathrm{~b}}$ to afford the $N_{3}-p$ methoxyphenoxyacetyloxazolidine-2-thione (11) in 69\% yield after chromatography and recrystallization (Scheme 1). Crystals suitable for x-ray crystallographic diffraction were grown by slow diffusion of hexanes into an ethyl acetate solution of $\mathbf{1 1}$. The collected X-ray crystal data revealed the expected anti-parallel arrangement of the thione moiety and the $\mathrm{N}_{3}$-carbonyl group (Scheme 1).

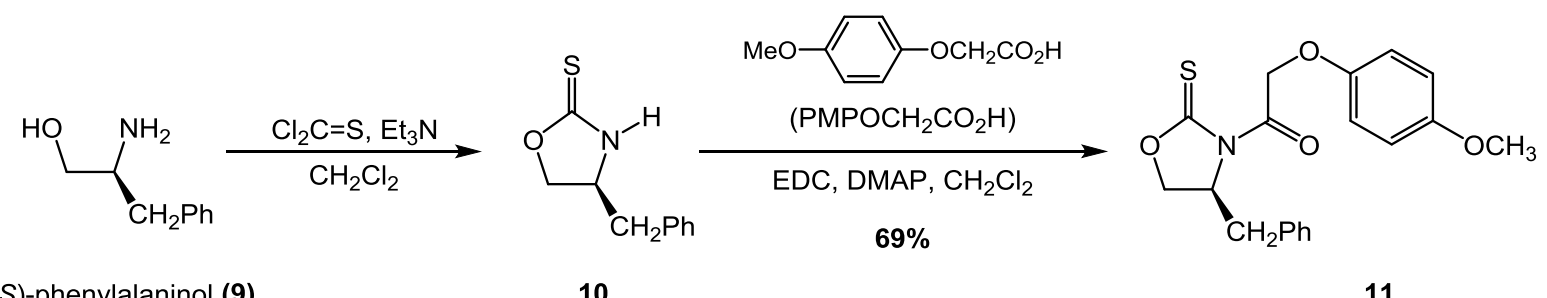

(S)-phenylalaninol (9)

10

11

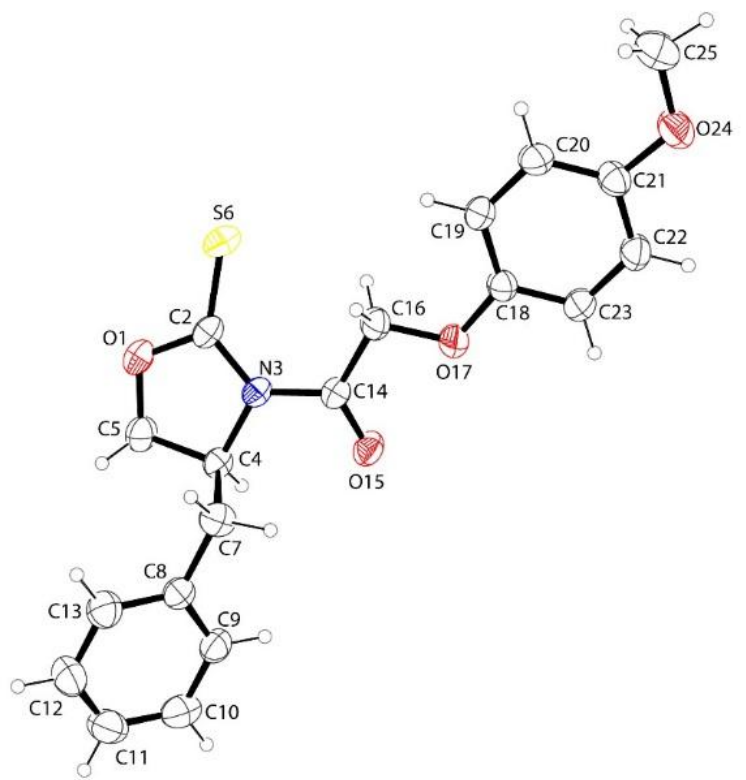

Scheme 1. Synthesis and X-ray crystal structure of oxazolidine-2-thione 11.

With the oxazoldine-2-thione in hand, we conducted a series of titanium mediated glycolate aldol addition reactions using reaction conditions modified from those described by Crimmins 
and coworkers. ${ }^{18}$ Thus, the acylated thione $\mathbf{1 1}$ was dissolved in dichloromethane, cooled to -25 ${ }^{\circ} \mathrm{C}$ and treated with $\mathrm{TiCl}_{4}$ to cause complexation. Hünig's base was added to cause the formation of the titanium enolate, and this was followed by the addition of N-methylpyrrolidine (NMP). The aldehyde was then added to this mixture to afford the final aldol addition product after purification. The results of the addition reactions are illustrated in Table 1.

Table 1. Asymmetric glycolate aldol addition reaction with 11.

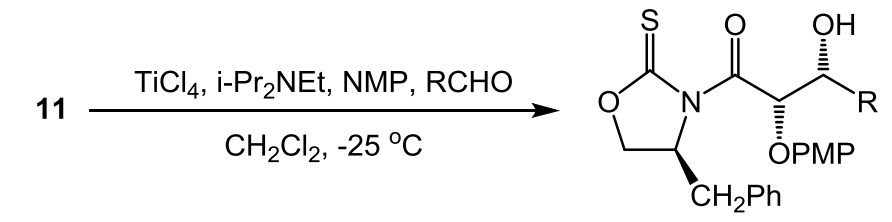

12

\begin{tabular}{ccccc}
\hline entry & Aldehyde, $\mathrm{RCHO}$ & adduct & d.r. $^{a}$ & yield $^{b}$ \\
\hline $\mathbf{1}$ & $\mathrm{C}_{6} \mathrm{H}_{5^{-}}$ & $\mathbf{1 2 a}$ & $80: 20$ & 89 \\
$\mathbf{2}$ & $p-\mathrm{ClC}_{6} \mathrm{H}_{4^{-}}$ & $\mathbf{1 2 b}$ & $70: 30$ & 91 \\
$\mathbf{3}$ & $p-\mathrm{BrC}_{6} \mathrm{H}_{4^{-}}$ & $\mathbf{1 2 c}$ & $73: 27$ & 69 \\
$\mathbf{4}$ & $o-\mathrm{FC}_{6} \mathrm{H}_{4} 4^{-}$ & $\mathbf{1 2 d}$ & $71: 29$ & 65 \\
$\mathbf{5}$ & $m-\mathrm{NO}_{2} \mathrm{C}_{6} \mathrm{H}_{4^{-}}$ & $\mathbf{1 2 e}$ & $75: 25$ & 23 \\
$\mathbf{6}$ & $2-\mathrm{C}_{10} \mathrm{H}_{7^{-}}$ & $\mathbf{1 2 f}$ & $76: 24$ & 69 \\
$\mathbf{7}$ & $(E)-\mathrm{PhCH} \mathrm{CH}-$ & $\mathbf{1 2 g}$ & $74: 26$ & 98 \\
$\mathbf{8}$ & $\left(\mathrm{CH}_{3}\right)_{2} \mathrm{CHCH}_{2^{-}}$ & $\mathbf{1 2 h}$ & $73: 27$ & 91 \\
$\mathbf{9}$ & $\left(\mathrm{CH}_{3}\right)_{3} \mathrm{C}-$ & $\mathbf{1 2 i}$ & $62: 38$ & 56 \\
\hline
\end{tabular}


${ }^{a}$ The crude diastereomeric ratios were determined by ${ }^{1} \mathrm{H}$ NMR spectroscopy. ${ }^{b}$ Isolated chemical yield after flash chromatography.

The isolated chemical yields ranged from 56 to $98 \%$, and the diastereoselectivities ranged from 62:38 to 80:20 favoring the dominant stereoisomer. The low diastereoselectivities were attributed to the elevated temperature and so the reaction conditions were modified. In an effort to improve the outcome of the glycolate aldol reaction, the temperature was lowered from $-25{ }^{\circ} \mathrm{C}$ to $-78{ }^{\circ} \mathrm{C}$, Hünig's base was replaced with triethylamine, and the solvent additive NMP was eliminated from the reaction. These changes afforded improved results in the crude diastereoselectivity, but not in the isolated yields (Table 2).

Table 2. Modified conditions for the asymmetric glycolate aldol addition reaction with $\mathbf{1 1}$.

$$
11 \underset{\mathrm{CH}_{2} \mathrm{Cl}_{2},-78^{\circ} \mathrm{C}}{\stackrel{\mathrm{TiCl}_{4}, \mathrm{TEA}, \mathrm{RCHO}}{\longrightarrow}} 12
$$

\begin{tabular}{ccccc}
\hline entry & Aldehyde, $\mathrm{RCHO}$ & adduct & d.r. $^{a}$ & yield $^{b}$ \\
\hline $\mathbf{1}$ & $\mathrm{C}_{6} \mathrm{H}_{5^{-}}$ & $\mathbf{1 2 a}$ & $93: 7$ & $71^{c}$ \\
$\mathbf{2}$ & $p-\mathrm{ClC}_{6} \mathrm{H}_{4^{-}}$ & $\mathbf{1 2 b}$ & $91: 9$ & 47 \\
$\mathbf{3}$ & $p-\mathrm{BrC}_{6} \mathrm{H}_{4^{-}}$ & $\mathbf{1 2 c}$ & $94: 6$ & 83 \\
$\mathbf{4}$ & $o-\mathrm{FC}_{6} \mathrm{H}_{4^{-}}$ & $\mathbf{1 2 d}$ & $75: 25$ & 86 \\
$\mathbf{5}$ & $m-\mathrm{NO}_{2} \mathrm{C}_{6} \mathrm{H}_{4^{-}}$ & $\mathbf{1 2 e}$ & $88: 12$ & 82 \\
$\mathbf{6}$ & $2-\mathrm{C}_{10} \mathrm{H}_{7^{-}}$ & $\mathbf{1 2 f}$ & $93: 7$ & 52 \\
$\mathbf{7}$ & $(E)-\mathrm{PhCH}=\mathrm{CH}-$ & $\mathbf{1 2 g}$ & $94: 6$ & 89
\end{tabular}




\begin{tabular}{|c|c|c|c|c|}
\hline 8 & $\left(\mathrm{CH}_{3}\right)_{2} \mathrm{CHCH}_{2-}$ & $12 \mathrm{~h}$ & $87: 13$ & 95 \\
\hline 9 & $\left(\mathrm{CH}_{3}\right)_{3} \mathrm{C}-$ & $12 \mathbf{i}$ & $\mathrm{n} / \mathrm{a}^{d}$ & $\mathrm{n} / \mathrm{a}$ \\
\hline \multicolumn{5}{|c|}{${ }^{a_{T}}$ The crude diastereomeric ratios were determined by ${ }^{1} \mathrm{H}$} \\
\hline \multicolumn{5}{|c|}{ NMR spectroscopy. ${ }^{b}$ Isolated chemical yield after flash } \\
\hline
\end{tabular}

We were pleased with the improved results from the aldol addition reaction and conducted a stereochemical analysis of the products. In this context, analysis of the NMR spectrum of 12a revealed that the ${ }^{3} J_{\mathrm{Ha} / \mathrm{Hb}}$ coupling constant between the glycolytic proton $\mathrm{H}_{\mathrm{a}}$ and the benzylic proton $\mathrm{H}_{\mathrm{b}}$ was $4.65 \mathrm{~Hz}$ (Scheme 2). This suggested a syn-configuration for 12a and by correlation, for $\mathbf{1 2 b}-\mathbf{1 2} \mathbf{i}$. Methanolysis of 12a with methanol and imidazole yielded the methyl ester in $87 \%$ yield. The ${ }^{3} J_{\mathrm{Ha} / \mathrm{Hb}}$ coupling constant of $5.29 \mathrm{~Hz}$ between the same two protons further suggested the syn- aldol relationship. The specific rotation of the methyl ester was determined to be $[\alpha]_{\mathrm{D}}{ }^{24}=-28.6\left(c=0.688, \mathrm{CHCl}_{3}\right)$. This was in agreement with the literature value of the $(2 S, 3 R)$-enantiomer $\left\{[\alpha]_{\mathrm{D}}{ }^{24}=-25.0\left(c=0.35, \mathrm{CHCl}_{3}\right)\right\}$ that had been previously prepared by our group. ${ }^{16}$ The absolute stereochemistry of the glycolate aldol adduct $\mathbf{1 2 a}$ was further confirmed by X-ray crystallographic analysis (Figure 1). Based on the observed (2S,3R)stereochemistry of the product, the transition state model that was proposed by Crimmins and McDougall was invoked.

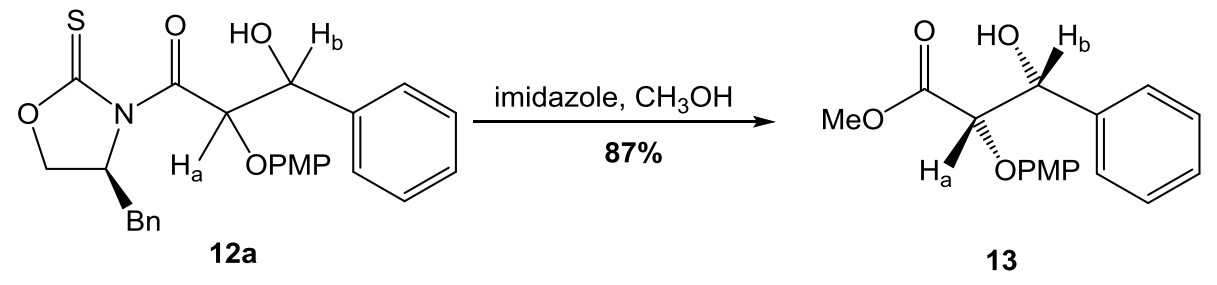


Scheme 2. Stereochemical determination.

Interestingly, in the course of analyzing the $500 \mathrm{MHz}{ }^{1} \mathrm{H}$ NMR spectra of aldol adducts 12ai, it was determined that the glycolic $\alpha$-proton was not in the expected region of the NMR spectrum near $6.0 \mathrm{ppm}$ (Figure 2). Crimmins and $\mathrm{McDougall}^{\text {7h }}$ had prepared a syn-glycolate oxazolidine-2-thione derivative (16) in which the glycolic $\alpha$-proton appeared at a resonance of $6.04 \mathrm{ppm}$. A COSY ${ }^{1} \mathrm{H}$ NMR spectrum revealed that the signal in question appeared at $7.24 \mathrm{ppm}$ in aldol adduct 12a. The deviation of the chemical shift of the $\alpha$-proton from the expected value was attributed to the presence of a deshielding region proximal to the $\alpha$-proton.

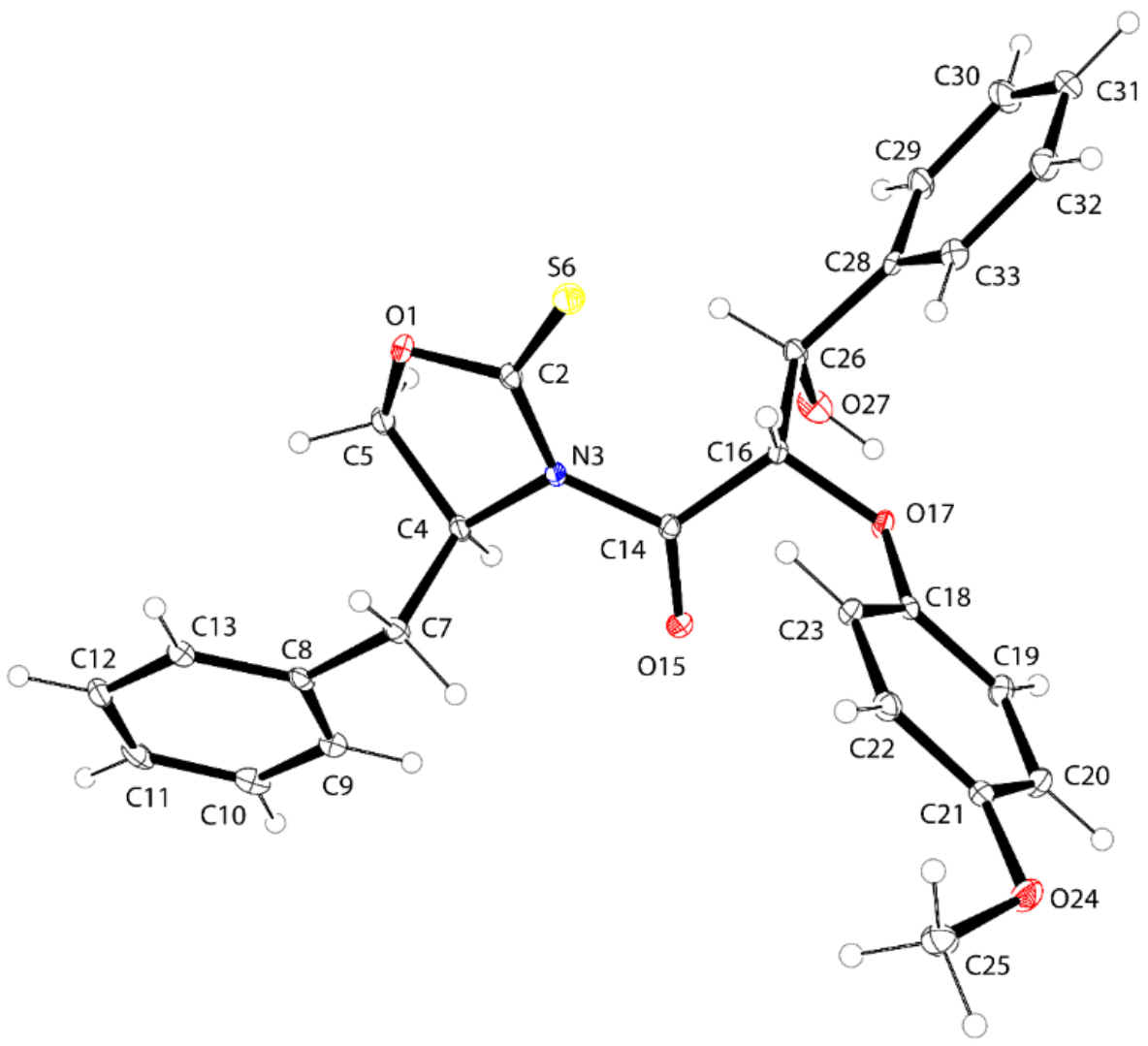

Figure 1. X-ray crystal structure of glycolate aldol adduct 12a. 


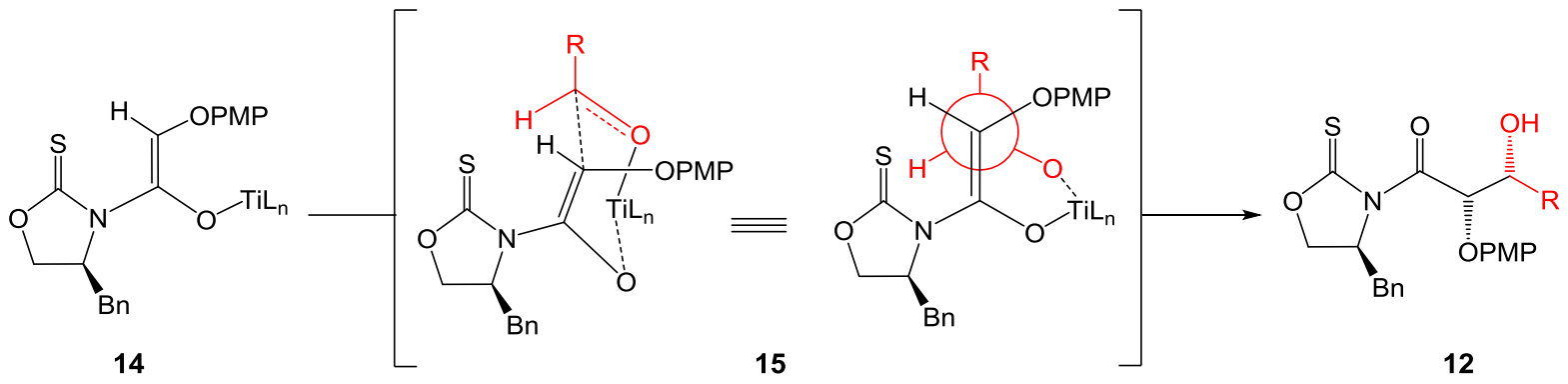

Scheme 3: Proposed transition state of the major aldol product.

The origin of the deshielding effect was unclear, but was most likely be due to the glycolytic proton being in the deshielding cone of an aromatic system. A conformational evaluation of 12a provided some insight into the unusual chemical shift value. The X-ray crystal structure of 12a suggests that the $\mathrm{N}_{3}$-amide carbonyl and the thiocarbonyl group share an anti-parallel arrangement. This same arrangement may well be present in the solution state due to favorable dipole minimization. Based on this configurational arrangement, the benzyl substituent of the oxazolidine-2-thione is not suspected as the origin of the deshielding effect; its proximity to the deshielded $\alpha$-proton is not sufficient. The appendant phenyl ring of the $\mathrm{N}_{3}$-aldol side chain in 12a is not suspected as all of the aldol adducts (12a-i) share this deshielded proton, regardless of the presence of an aryl group (12a-g) or alkyl group (12h-i). Specifically, oxazolidine-2-thione 12h possesses a tert-butyl group at the end of the $\mathrm{N}_{3}$-aldol side chain, and the observed chemical shift of this deshielded proton is $7.13 \mathrm{ppm}$ (Figure 2). Based on these observations, it is proposed that the aromatic ring of the $p$-methoxyphenoxy group is the source of the deshielding. This argument is supported by the fact that the methanolysis of 12a to give $\mathbf{1 3}$ causes the glycolytic proton to appear at $5.07 \mathrm{ppm}$ in the cleaved ester. 


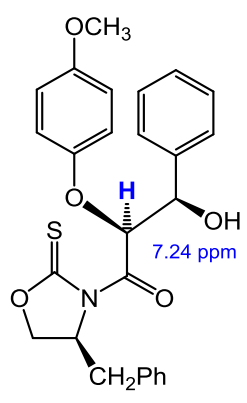

$12 a$

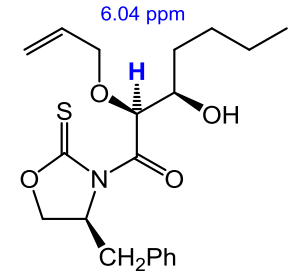

16, Crimmins and McDougall

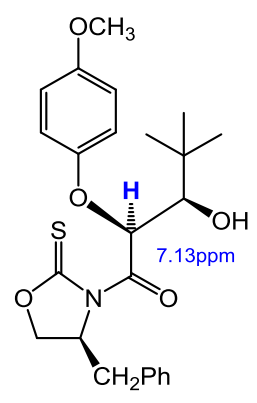

$12 \mathrm{~h}$

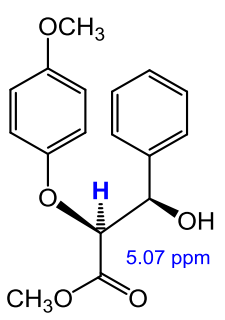

13

Figure 2. Comparison of the $\alpha$-proton of glycolate aldol adducts.

\section{Conclusion}

In summary, the p-methoxyphenoxy group has much potential as a protecting group in glycolate chemistry as it is removed under conditions orthogonal to many alcohol protecting groups. We have prepared a $\mathrm{N}_{3}-p$-methoxyphenoxyacetyloxazolidine-2-thione and applied it in the asymmetric glycolate aldol addition reaction. The initial conditions employing titanium tetrachloride, Hünig's base, and NMP yielded moderate to excellent yields, but low diastereoselectivities. The optimized reaction conditions involving the lower temperature and the elimination of NMP proved afforded improved diastereoselection, but did not improve the yield. The absolute stereochemistry was determined and confirmed through a combination of ${ }^{1} \mathrm{H}$ NMR spectroscopy and X-ray crystallography. A ${ }^{1} \mathrm{H}$ NMR COSY revealed that the $\alpha$-glycolytic proton was highly deshielded. The origin of the deshielding is postulated to be due to the presence of the highly deshielded glycolic $\alpha$-proton in the aldol adducts was attributed to the presence of the $p$ methoxyphenoxy group.

\section{Experimental section}




\subsection{General information}

All chemical reagents were used as purchased. All reaction vessels were flame dried and purged under a nitrogen atmosphere. All NMR spectra were recorded in $\mathrm{CDCl}_{3}$ and reported in parts per million ( $\delta$ scale) with tetramethylsilane as an internal standard $\left(\delta=0 \mathrm{ppm},{ }^{1} \mathrm{H}\right)$ or deuterated chloroform as a standard $\left(\delta=77.0 \mathrm{ppm},{ }^{13} \mathrm{C}\right)$. Optical rotation data was collected on a JASCO P-1010 digital polarimeter operating at $589 \mathrm{~nm}$ in an $8 \times 100 \mathrm{~mm}$ cell. Melting points were determined using a Laboratory Devices Mel-Temp apparatus and are uncorrected.

\section{2. (S)-4-Benzyl-3-[(p-methoxyphenoxy)acetyl]oxazolidine-2-thione (11)}

In a $100 \mathrm{~mL}$, flame dried, nitrogen purged round bottom flask equipped with a magnetic stir bar (S)-4-benzyl-1,3-oxazolidine-2-thione (15.0 g, $77.9 \mathrm{mmol}), \mathrm{CH}_{2} \mathrm{Cl}_{2}$ (312 mL), 1-ethyl-3(3-dimethylamino propyl) carbodiimide (EDC, 16.4 g, $85.5 \mathrm{mmol})$, DMAP (2.38 g, $19.5 \mathrm{mmol})$, and $p$-methoxy-phenoxyacetic acid $(14.2 \mathrm{~g}, 77.9 \mathrm{mmol})$ was added sequentially and stirred overnight. The reaction was quenched, extracted and the solvents removed in vacuo. The crude product was purified by flash column chromatography (hexanes: EtOAc, gradient: 80:20 to 65:35) to yield $19.3 \mathrm{~g}(69 \%)$ of the title compound as an off-white solid. Melting Point: $86-88$

${ }^{\circ} \mathrm{C} .{ }^{1} \mathrm{H}$ NMR $\left(400 \mathrm{MHz}, \mathrm{CDCl}_{3}\right): \delta 2.83(\mathrm{dd}, J=10.0,3.3 \mathrm{~Hz}, 1 \mathrm{H}), 3.33(\mathrm{dd}, J=10.0,3.3 \mathrm{~Hz}$, $1 \mathrm{H}), 3.78(\mathrm{~s}, 3 \mathrm{H}), 4.40-4.45(\mathrm{~m}, 2 \mathrm{H}), 4.95-5.01(\mathrm{~m}, 1 \mathrm{H}), 5.55(\mathrm{q}, J=17.8 \mathrm{~Hz}, 2 \mathrm{H}), 6.83-6.89(\mathrm{~m}$, 2H), 6.91-6.95 (m, 2H), 7.21-7.24 (m, 2H), 7.28-7.37 (m, 3H). $\left.{ }^{13} \mathrm{C} \mathrm{NMR} \mathrm{(125} \mathrm{MHz,} \mathrm{CDCl}\right): \delta$ $37.54,55.72,59.90,70.22,71.65,114.79,116.04,127.58,129.12,129.42,134.90,151.96$, 
154.51, 169.51, 184.85. IR (nujol mull): $1707,1365,1329,1196,754,733,700 \mathrm{~cm}^{-1} \cdot[\alpha]^{23}{ }_{\mathrm{D}}=$ $+85.0\left(c\right.$ 1.02, $\left.\mathrm{CHCl}_{3}\right)$. ESI HRMS for $\mathrm{C}_{19} \mathrm{H}_{19} \mathrm{NO}_{4} \mathrm{~S}:$ calc $\left(\mathrm{M}+\mathrm{H}^{+}\right) 358.1121$, found 358.1113 .

\subsection{General procedure for the asymmetric glycolate aldol addition reaction.}

\section{Method A:}

In a $250 \mathrm{~mL}$, flame dried, nitrogen purged round bottom flask equipped with a magnetic stir bar, oxazolidine-2-thione $11(0.500 \mathrm{~g}, 1.40 \mathrm{mmol})$, and $\mathrm{CH}_{2} \mathrm{Cl}_{2}(10 \mathrm{~mL})$ were cooled to -25 ${ }^{\circ} \mathrm{C}$ before the addition of $\mathrm{TiCl}_{4}(0.160 \mathrm{~mL}, 1.54 \mathrm{mmol})$. The reactants were allowed stir for 30 minutes and then the addition of di-isopropylethylamine $(0.61 \mathrm{~mL}, 3.5 \mathrm{mmol})$ followed. The mixture was stirred for one hour and $N$-methylpyrrolidinone (NMP) $(0.13 \mathrm{~mL} 1.4 \mathrm{mmol})$ was added and the reaction stirred for 30 minutes. The aldehyde $(2.1 \mathrm{mmol})$ was added and the reaction stirred for 4 hours at $-25{ }^{\circ} \mathrm{C}$. The reaction was quenched by the addition of brine $(3 \mathrm{~mL})$. The reaction mixture was diluted with $\mathrm{CH}_{2} \mathrm{Cl}_{2}(50 \mathrm{~mL})$ and treated with $1 \mathrm{M} \mathrm{HCl}(30 \mathrm{~mL})$, and subsequently treated with brine $(30 \mathrm{~mL})$. Method B: In a $250 \mathrm{~mL}$, flame dried, nitrogen purged round bottom flask equipped with a magnetic stir bar was placed the oxazolidin-2-thione $\mathbf{1 1}$ (0.500 g, $1.40 \mathrm{mmol}, 1$ equiv), and $\mathrm{CH}_{2} \mathrm{Cl}_{2}(10 \mathrm{~mL})$ were cooled to $-78^{\circ} \mathrm{C}$ before the addition of $\mathrm{TiCl}_{4}(0.160 \mathrm{~mL}, 1.54 \mathrm{mmol})$. The reactants were allowed stir for 30 minutes. Then the addition of TEA $(0.50 \mathrm{~mL}, 3.50 \mathrm{mmol})$ occurred and was allowed to stir for one hour. The aldehyde (2.52 mmol) was added and allowed stir for 6 hours at $-78^{\circ} \mathrm{C}$. The reaction was quenched with brine ( 3 $\mathrm{mL}$ ). The product was extracted by dilution with $50 \mathrm{~mL} \mathrm{CH}_{2} \mathrm{Cl}_{2}$ with one treatment of $1 \mathrm{M} \mathrm{HCl}$ $(30 \mathrm{~mL})$ and brine $(30 \mathrm{~mL})$. The crude product was purified by flash column chromatography (hexanes: EtOAc, 75:25). Method C: In a $1 \mathrm{~L}$, flame dried, nitrogen purged round bottom flask equipped with a magnetic stir bar was placed $11(5.00 \mathrm{~g}, 1.40 \mathrm{mmol})$, and $\mathrm{CH}_{2} \mathrm{Cl}_{2}(140 \mathrm{~mL})$ were 
cooled to $-78^{\circ} \mathrm{C}$ before the addition of $\mathrm{TiCl}_{4}(1.60 \mathrm{~mL}, 1.54 \mathrm{mmol})$. The reactants were allowed stir for 45 minutes. Then the addition of TEA $(0.50 \mathrm{~mL}, 3.50 \mathrm{mmol})$ occurred and was allowed to stir for 75 minutes. The benzaldehyde $(2.60 \mathrm{~mL}, 2 . \mathrm{mmol})$ was added and allowed stir for 6 hours at $-78{ }^{\circ} \mathrm{C}$. The reaction was quenched with brine $(5 \mathrm{~mL})$. The product was extracted by dilution with $80 \mathrm{~mL} \mathrm{CH}_{2} \mathrm{Cl}_{2}$ and treated with $1 \mathrm{M} \mathrm{HCl}(35 \mathrm{~mL})$ and brine $(35 \mathrm{~mL})$. The extracted crude product was then dried $\left(\mathrm{MgSO}_{4}\right)$. The product was determined to have diastereoselectivity of 92:8 by 1H NMR spectroscopy and was recrystallized from hexanes and ethyl acetate yielding $4.60 \mathrm{~g}(9.94 \mathrm{mmol}, 71 \%)$ of white crystals of $\mathbf{1 2 a}$.

\subsection{1. (2S,3R)-4-Benzyl-3-[(3-hydroxy-2-(p-methoxyphenoxy)-3-phenylpropanoyl] oxazolidine-2-thione (12a).}

The title compound was purified by flash column chromatography (hexanes: EtOAc, 75:25) to yield $0.583 \mathrm{~g}(1.26 \mathrm{mmol}, 89 \%)$ of white crystals via Method A. By Method C, the crude product was recrystallized to yield $4.60 \mathrm{~g}$ (9.94 mmol, $71 \%$ ). Melting point: $154-157{ }^{\circ} \mathrm{C}$.

${ }^{1} \mathrm{H}$ NMR (500 MHz, $\left.\mathrm{CDCl}_{3}\right): \delta 2.78(\mathrm{dd}, J=13.4,9.9 \mathrm{~Hz}, 1 \mathrm{H}), 3.19(\mathrm{dd}, J=13.4,3.1 \mathrm{~Hz}, 1 \mathrm{H})$, $3.77(\mathrm{~s}, 3 \mathrm{H}), 3.89$ (dd, $J=8.5,7.3 \mathrm{~Hz}, 1 \mathrm{H}), 4.24(\mathrm{dd}, J=8.9,1.3 \mathrm{~Hz}, 1 \mathrm{H}), 4.62-4.66(\mathrm{~m}, 1 \mathrm{H})$, $5.27(\mathrm{~d} J=4.65 \mathrm{~Hz}, 1 \mathrm{H}), 6.84(\mathrm{~d}, J=9.4 \mathrm{~Hz}, 2 \mathrm{H}), 6.99(\mathrm{~d}, J=8.45 \mathrm{~Hz}, 2 \mathrm{H}), 7.15(\mathrm{~d}, J=6.15$ $\mathrm{Hz}, 1 \mathrm{H}), 7.24(\mathrm{~d}, J=4.65 \mathrm{~Hz}, 1 \mathrm{H}), 7.33(\mathrm{~m}, 8 \mathrm{H}), 7.55(\mathrm{~d}, J=7.5 \mathrm{~Hz}, 1 \mathrm{H}) .{ }^{13} \mathrm{C} \mathrm{NMR}(125 \mathrm{MHz}$, $\left.\mathrm{CDCl}_{3}\right) 3.41,55.70,61.01,70.78,75.46,79.74,114.78,117.07,126.71,127.51,128.33,128.50$, 129.00, 129.46, 134.79, 138.24, 151.17, 154.92, 170.75, 184.89. IR (nujoll mull): 3550, 1720, $1231,1062,829,742,692 \mathrm{~cm}^{-1} .[\alpha]^{23}{ }^{2}=+148\left(c 1.00, \mathrm{CHCl}_{3}\right)$. Melting point: $154-15{ }^{\circ} \mathrm{C}$. ESIHRMS for $\mathrm{C}_{26} \mathrm{H}_{25} \mathrm{NO}_{5} \mathrm{~S}$ : calc'd $\left(\mathrm{M}+\mathrm{H}^{+}\right)$464.1526; found 464.1522.

\subsection{2. (2S,3R)-4-Benzyl-3-(( $p$-chlorophenyl)-3-hydroxy-2-(p-methoxyphenoxy)propanoyl)}


oxazolidine-2-thione (12b).

The title compound was purified by flash column chromatography (hexanes: EtOAc, 75:25) to yield yield of $0.641 \mathrm{~g}$ ( $1.33 \mathrm{mmol}, 91 \%)$ of white crystals via Method A; Method B $0.331 \mathrm{~g}$ (0.667 mmol, 48\%). Melting Point: 153-155 ${ }^{\circ} \mathrm{C} .{ }^{1} \mathrm{H}$ NMR (500 $\left.\mathrm{MHz}, \mathrm{CDCl}_{3}\right)$ : $\delta 2.77(\mathrm{dd}, J=13.5,9.9 \mathrm{~Hz}, 1 \mathrm{H}), 3.18(\mathrm{dd}, J=13.5,3.15 \mathrm{~Hz}, 1 \mathrm{H}), 3.74(\mathrm{~s}, 3 \mathrm{H}), 4.05(\mathrm{dd}, J=8.9$, $6.5,1 \mathrm{H}), 4.31(\mathrm{dd}, J=9.3,1.7 \mathrm{~Hz}, 1 \mathrm{H}), 4.71-4.75(\mathrm{~m}, 1 \mathrm{H}), 5.28(\mathrm{~d}, J=3.8 \mathrm{~Hz}, 1 \mathrm{H}), 8.80(\mathrm{~d}, J=$ $9.2 \mathrm{~Hz}, 2 \mathrm{H}), 6.90(\mathrm{~d}, J=9.2 \mathrm{~Hz}, 2 \mathrm{H}), 7.13(\mathrm{~d}, J=6.7 \mathrm{~Hz}, 1 \mathrm{H}), 7.18(\mathrm{~d}, J=3.6 \mathrm{~Hz}, 1 \mathrm{H}), 7.26-$ $7.33(\mathrm{~m}, 7 \mathrm{H}), 7.48(\mathrm{~d}, J=8.7 \mathrm{~Hz}, 2 \mathrm{H}) .{ }^{13} \mathrm{C} \mathrm{NMR}\left(125 \mathrm{MHz}, \mathrm{CDCl}_{3}\right): \delta 37.37,55.68,60.98$, $70.96,74.22,79.50,114.82,115.01,116.95,127.589,127.95,128.48,129.05,129.45,134.19$ 134.66, 137.16, 151.01, 155.01, 170.34, 184.96. IR $\left(\mathrm{CHCl}_{3}\right): 3478,2837,1702,1506,1368$, 1328, 1092, 822, $703 \mathrm{~cm}^{-1} .[\alpha]^{24}=+124\left(c 1.00, \mathrm{CHCl}_{3}\right)$. ESI HRMS for $\mathrm{C}_{26} \mathrm{H}_{24} \mathrm{ClNO}_{5} \mathrm{~S}$ : calc'd $\left(\mathrm{M}+\mathrm{H}^{+}\right)$498.1143, found 498.1136.

\subsection{3. (2S,3R)-4-Benzyl-3-[(p-bromophenyl)-3-hydroxy-2-(p-methoxyphenoxy)propanoyl] oxazolidine-2-thione (12c).}

The titled product was purified by flash column chromatography (hexanes: EtOAc, 75:25) to yield $0.539 \mathrm{~g}(0.987 \mathrm{mmol}, 69 \%)$ of viscous yellow oil of product via Method A and $0.625 \mathrm{~g}(1.16 \mathrm{mmol}, 83 \%)$ of tan powder via Method B. Melting point: $147-150{ }^{\circ} \mathrm{C}$. ${ }^{1} \mathrm{H}$ NMR $\left(500 \mathrm{MHz}, \mathrm{CDCl}_{3}\right): \delta 2.77(\mathrm{dd}, J=13.4,9.8,1 \mathrm{H}), 3.18(\mathrm{dd}, J=13.4,2.9 \mathrm{~Hz}, 1 \mathrm{H}), 3.74(\mathrm{~s}, 3 \mathrm{H})$, $4.05(\mathrm{dd}, J=16.4,8.2 \mathrm{~Hz}, 1 \mathrm{H}), 4.31(\mathrm{~d}, J=9.2 \mathrm{~Hz}, 1 \mathrm{H}), 4.73(\mathrm{t}, J=8.2 \mathrm{~Hz}, 1 \mathrm{H}), 5.26(\mathrm{~d}, J=$ 3.7 Hz, 1 H), 6.81( d, $J=8.8 \mathrm{~Hz}, 2 \mathrm{H}), 6.90(\mathrm{~d}, J=9.3 \mathrm{~Hz}, 2 \mathrm{H}), 7.13(\mathrm{~d}, J=6.7 \mathrm{~Hz}, 2 \mathrm{H}), 7.18$ $(\mathrm{d}, J=3.65 \mathrm{~Hz}, 1 \mathrm{H}), 7.28(\mathrm{~m}, 2 \mathrm{H}), 7.42(\mathrm{~d}, J=8.8 \mathrm{~Hz}, 2 \mathrm{H})$, and $7.48 \mathrm{ppm}(\mathrm{d}, J=8.3 \mathrm{~Hz}, 2 \mathrm{H})$.

${ }^{13} \mathrm{C}$ NMR (125 MHz, $\left.\mathrm{CDCl}_{3}\right): \delta 37.44,55.76,61.04,71.02,74.35,79.48,114.86,116.95$, 
$122.38,127.62,128.28,129.09,129.49,131.49,134.67,137.70,151.01,155.08,170.34$, and 185.00 ppm. IR $\left(\mathrm{CHCl}_{3}\right): 3451,2957,1708,1508,1367,1328,1070,829,702 \mathrm{~cm}^{-1} \cdot[\alpha]^{23}{ }_{\mathrm{D}}=$ +130 (c 1.00, $\mathrm{CHCl}_{3}$ ). ESI HRMS for $\mathrm{C}_{26} \mathrm{H}_{24} \mathrm{BrNO}_{5} \mathrm{~S}$ : calc'd $\left(\mathrm{M}+\mathrm{H}^{+}\right)$542.0638, found 542.0632.

\subsection{4. (2S,3R)-4-Benzyl-3-[(o-fluorophenyl)-3-hydroxy-2-(p-methoxyphenoxy)propanoyl] Oxazolidine-2-thione (12d).}

The title compound was purified by flash column chromatography (hexanes: EtOAc, $75: 25)$ to yield $0.469 \mathrm{~g}(0.975 \mathrm{mmol}, 65 \%)$ of yellow viscous oil via Method A and $0.576 \mathrm{~g}(1.20$ mmol, 86\%) of white crystals via Method B. Melting Point: $122-124{ }^{\circ} \mathrm{C} .{ }^{1} \mathrm{H}$ NMR $(500 \mathrm{MHz}$, $\left.\mathrm{CDCl}_{3}\right): \delta 2.69(\mathrm{dd}, J=10.2,13.4,1 \mathrm{H}), 3.11-3.16(\mathrm{~m}, 2 \mathrm{H}), 3.68$ (singlet, $\left.3 \mathrm{H}\right), 3.93(\mathrm{t}, J=8.0$, $1 \mathrm{H}), 4.19(\mathrm{~d}, J=9.3,1 \mathrm{H}), 4.65-4.69(\mathrm{~m}, 1 \mathrm{H}), 5.44(\mathrm{t}, J=5.65,1 \mathrm{H}), 6.76(\mathrm{~d}, J=9.2,2 \mathrm{H}), 6.91$ (d, $J=8.9 \mathrm{~Hz}, 2 \mathrm{H}), 6.98-6.94(\mathrm{~m}, 1 \mathrm{H}), 7.06-7.11(\mathrm{~m}, 4 \mathrm{H}), 7.17-7.24(\mathrm{~m}, 4 \mathrm{H}), 7.61(\mathrm{t}, J=7.1 \mathrm{~Hz}$, 1H). ${ }^{13} \mathrm{C}$ NMR $\left(125 \mathrm{MHz}, \mathrm{CDCl}_{3}\right): \delta 37.29,55.63,61.16,69.40\left(\mathrm{~d}, J_{\mathrm{C}-\mathrm{F}}=1.8 \mathrm{~Hz}\right), 78.69,114.77$, $114.92\left(\mathrm{~d}, J_{\mathrm{C}-\mathrm{F}}=21.8 \mathrm{~Hz}\right), 116.75,124.36\left(\mathrm{~d}, J_{\mathrm{C}-\mathrm{F}}=2.6 \mathrm{~Hz}\right), 125.29\left(\mathrm{~d}, J_{\mathrm{C}-\mathrm{F}}=12.7 \mathrm{~Hz}\right), 127.42$, $128.91,129.38\left(\mathrm{~d}, J_{\mathrm{C}-\mathrm{F}}=3.64 \mathrm{~Hz}\right), 129.44,130.11\left(\mathrm{~d}, J_{\mathrm{C}-\mathrm{F}}=8.2 \mathrm{~Hz}\right), 134.76,154.04,154.77$, $159.95\left(\mathrm{~d}, J_{\mathrm{C}-\mathrm{F}}=247.1 \mathrm{~Hz}\right), 170.19,184.68$ ppm. IR $\left(\mathrm{CHCl}_{3}\right): 3414,2837,1705,1507,1365$ $1329,1108,828,702 \mathrm{~cm}^{-1} \cdot[\alpha]^{24}=+16\left(c 1.00, \mathrm{CHCl}_{3}\right)$. ESI HRMS for $\mathrm{C}_{26} \mathrm{H}_{24} \mathrm{FNO}_{5} \mathrm{~S}$ : calc'd $\left(\mathrm{M}+\mathrm{H}^{+}\right)$482.1439, found 482.1426.

\subsection{5. (2S,3R)-4-Benzyl-3-[(3-hydroxy-2-(p-methoxyphenoxy)-3-(m-nitrophenyl)propanoyl] oxazolidine-2-thione (12e).}


The title compound was purified by flash column chromatography (hexanes: EtOAc, $75: 25)$ to yield $0.167 \mathrm{~g}(0.337 \mathrm{mmol} .23 \%)$ of yellow oil via Method A and $0.586(1.15 \mathrm{mmol}$, $82 \%$ ) of light yellow crystals via Method B. Melting Point: $142-143{ }^{\circ} \mathrm{C} .{ }^{1} \mathrm{H}$ NMR (500 MHz, $\left.\mathrm{CDCl}_{3}\right): \delta 2.58(\mathrm{dd}, J=13.4,9.8 \mathrm{~Hz}, 1 \mathrm{H}), 3.13-3.17(\mathrm{~m}, 2 \mathrm{H}), 3.66(\mathrm{~s}, 3 \mathrm{H}), 4.22(\mathrm{dd}, J=8.9,7.5$ $\mathrm{Hz}, 2 \mathrm{H}), 4.33(\mathrm{dd}, J=9.4,2.1 \mathrm{~Hz}, 1 \mathrm{H}), 4.84-4.84(\mathrm{~m}, 1 \mathrm{H}), 5.41(\mathrm{dd}, J=8.2,2.9 \mathrm{~Hz}, 1 \mathrm{H}), 6.71-$ 6.77, (m, 4H), 7.07 (dd, $J=8.2,1.9 \mathrm{~Hz}, 2 \mathrm{H}), 7.17-7.26(\mathrm{~m}, 3 \mathrm{H}), 7.48,(\mathrm{t}, J=15.8,7.9 \mathrm{~Hz}, 1 \mathrm{H})$, $7.84(\mathrm{~d}, J=7.7 \mathrm{~Hz}, 1 \mathrm{H}), 8.09(\mathrm{ddd}, J=5.1,2.2,0.9 \mathrm{~Hz}, 1 \mathrm{H})$, and 8.37-8.38 (m, 1H). ${ }^{13} \mathrm{C} \mathrm{NMR}$ (125 MHz, $\left.\mathrm{CDCl}_{3}\right): \delta 37.36,55.67,60.92,71.30,72.99,79.07,114.88,116.74,121.58,123.12$, $127.66,129.09,129.33,129.46,132.35,134.52,141.57,148.34,150.84,155.16,169.56,185.23$ ppm. IR $\left(\mathrm{CHCl}_{3}\right): 3404,2922,1709,1530,1350,1327,1070,827,702 \mathrm{~cm}^{-1} \cdot[\alpha]^{25}{ }_{\mathrm{D}}=+85(c$ 1.10, $\left.\mathrm{CHCl}_{3}\right)$. ESI HRMS for $\mathrm{C}_{26} \mathrm{H}_{24} \mathrm{~N}_{2} \mathrm{O}_{7} \mathrm{~S}$ : calc'd $\left(\mathrm{M}+\mathrm{H}^{+}\right)$498.1143, found 498.1136.

\subsection{6. (2S,3R)-4-Benzyl-3-[(3-hydroxy-2-(p-methoxyphenoxy)-3-(2-naphthyl)propanoyl]} oxazolidine -2-thione (12f).

The title compound was purified by flash column chromatography (hexanes: EtOAc, 75:25) to give a $69 \%$ yield $(0.498 \mathrm{~g}, 0.970 \mathrm{mmol})$ of small white crystals via Method A. For Method B, the product was recrystallization from ethyl acetate and hexanes. (0.723 mmol, 52\%) of white crystals. Melting Point: $160-162{ }^{\circ} \mathrm{C} .{ }^{1} \mathrm{H}$ NMR $\left(500 \mathrm{MHz}, \mathrm{CDCl}_{3}\right): \delta 2.66(\mathrm{dd}, J=13.4$, $9.8 \mathrm{~Hz}, 1 \mathrm{H}), 3.06(\mathrm{dd}, J=13.4,3.16 \mathrm{~Hz}, 1 \mathrm{H}), 3.10(\mathrm{~d}, J=6.3 \mathrm{~Hz}, 1 \mathrm{H}), 3.41(\mathrm{dd}, J=8.9,7.5 \mathrm{~Hz}$, 1H), $3.66(\mathrm{~s}, 3 \mathrm{H}), 4.01(\mathrm{dd}, J=9.2,1.6 \mathrm{~Hz}, 1 \mathrm{H}), 4.49-4.53(\mathrm{~m}, 1 \mathrm{H}), 5.33-5.36(\mathrm{~m}, 1 \mathrm{H}), 6.73(\mathrm{~d}, J$ $=9.2 \mathrm{~Hz}, 2 \mathrm{H}), 6.90(\mathrm{~d}, J=9.2 \mathrm{~Hz}, 2 \mathrm{H}), 7.16-7.22(\mathrm{~m}, 3 \mathrm{H}), 7.25(\mathrm{~d}, J=4.6 \mathrm{~Hz}, 1 \mathrm{H}), 7.38-7.41$ (m, 2H), 7.73-7.77 (m, 3H), $7.86(\mathrm{~s}, 1 \mathrm{H}) \mathrm{ppm} .{ }^{13} \mathrm{C} \mathrm{NMR}\left(125 \mathrm{MHz}, \mathrm{CDCl}_{3}\right): \delta 37.40,55.67$, $60.95,10.60,75.56,79.84,114.78,117.10,124.42,125.71,126.36,126.44,127.49,127.69$, $128.03,128.16,128.97,129.43,132.87,133.28,134.71,135.75,151.16,154.93,170.75,184.85$ 
ppm. IR $\left(\mathrm{CHCl}_{3}\right): 3444,2930,1704,1507,1364,1328,1108,825,702 \mathrm{~cm}^{-1} \cdot[\alpha]^{23}{ }_{\mathrm{D}}=+166(c$ 1.00, $\left.\mathrm{CHCl}_{3}\right)$. ESI HRMS for $\mathrm{C}_{30} \mathrm{H}_{27} \mathrm{NO}_{5} \mathrm{~S}$ : calc'd $\left(\mathrm{M}+\mathrm{H}^{+}\right)$514.1688, found 514.1689.

\subsection{7. $\quad(2 S, 3 R, E)-1-[(S)-4-B e n z y l-(3-h y d r o x y-2-(p-m e t h o x y p h e n o x y)-5-p h e n y l-4-p e n t e n o y l)$ oxazolidine-2-thione (12g).}

The title compound was purified by flash column chromatography (hexanes: EtOAc, $75: 25)$ to yield $0.682 \mathrm{~g}(1.39 \mathrm{mmol}, 98 \%)$ orange viscous oil via Method A and $0.680 \mathrm{~g}(1.24 \mathrm{~g}$, $89 \%)$ of white crystals via Method B. Melting point: $128-130{ }^{\circ} \mathrm{C} .{ }^{1} \mathrm{H} \mathrm{NMR}\left(500 \mathrm{MHz}, \mathrm{CDCl}_{3}\right): \delta$ $2.69(\mathrm{dd}, J=13.4,9.8 \mathrm{~Hz}, 1 \mathrm{H}), 3.08(\mathrm{dd}, J=134,3.1 \mathrm{~Hz}, 1 \mathrm{H}), 3.65(\mathrm{~s}, 1 \mathrm{H}), 3.94(\mathrm{dd}, J=9.1,7.5$ $\mathrm{Hz}, 1 \mathrm{H}), 4.17(\mathrm{dd}, J=9.3,1.7 \mathrm{~Hz}, 1 \mathrm{H}), 4.70-4.75(\mathrm{~m}, 1 \mathrm{H}), 4.79-4.81(\mathrm{~m}, 1 \mathrm{H}), 6.36(\mathrm{dd}, J=16.1$, $7.1 \mathrm{~Hz}, 1 \mathrm{H}), 6.61(\mathrm{~d}, J=15.9 \mathrm{~Hz}, 1 \mathrm{H}), 6.75(\mathrm{~d}, J=9.2 \mathrm{~Hz}, 2 \mathrm{H}), 6.90(\mathrm{~d}, J=9.1 \mathrm{~Hz}, 2 \mathrm{H}), 7.02-$ $7.04(\mathrm{~m}, 2 \mathrm{H}), 7.09(\mathrm{~d}, J=4.1 \mathrm{~Hz}, 1 \mathrm{H}), 7.13-7.15(\mathrm{~m}, 1 \mathrm{H}), 7.16-7.21(\mathrm{~m}, 5 \mathrm{H}), 7.27(\mathrm{~d}, J=7.3 \mathrm{~Hz}$ 2H). $\left.{ }^{13} \mathrm{C} \mathrm{NMR} \mathrm{(125} \mathrm{MHz,} \mathrm{CDCl}_{3}\right): \delta 37.45,55.72,60.89,71.02,74.19,78.98,114.91,116.82$, $126.38,126.73,127.53,128.24,128.73,129.02,129.47,132.95,134.79 .135 .98,151.36,154.91$, 170.36, 185.44 ppm. IR $\left(\mathrm{CHCl}_{3}\right): 3417,1710,1507,1366,1328,1071,828,702 \mathrm{~cm}^{-1} \cdot[\alpha]^{24}{ }_{\mathrm{D}}=$ $+205\left(c 1.00, \mathrm{CHCl}_{3}\right)$. ESI HRMS $\left(\mathrm{C}_{28} \mathrm{H}_{27} \mathrm{NO}_{5} \mathrm{~S}\right)$ : calc'd $\left(\mathrm{M}+\mathrm{H}^{+}\right)$490.1689, found 490.1682 .

\subsection{8. $\quad(2 S, 3 R)-4-B e n z y l-3-(3-h y d r o x y-2-(p-m e t h o x y p h e n o x y)-4,4-d i m e t h y l p e n t a n o y l)$ oxazolidine-2-thione (12h).}

The title compound was purified by flash column chromatography (hexanes: EtOAc, 75:25) to yield $0.348 \mathrm{~g}(0.784 \mathrm{mmol}, 56 \%)$ of a viscous oil for Method A. The use of Method B failed in the preparation of this compound. ${ }^{1} \mathrm{H}$ NMR $\left(500 \mathrm{MHz}, \mathrm{CDCl}_{3}\right): \delta 0.99(\mathrm{~s}, 9 \mathrm{H}), 2.26(\mathrm{~d}$, $J=8.71 \mathrm{~Hz}, 1 \mathrm{H}), 2.62(\mathrm{dd}, J=13.47 \mathrm{~Hz}, 9.80,1 \mathrm{H}), 3.02(\mathrm{dd}, J=13.44 \mathrm{~Hz}, 3.24,1 \mathrm{H}), 3.73(\mathrm{t}, J=$ 
$8.75 \mathrm{~Hz}, 1 \mathrm{H}), 4.23-4.26(\mathrm{~m}, 2 \mathrm{H}), 4.87-4.92(\mathrm{~m}, 1 \mathrm{H}), 6.79(\mathrm{~d}, J=9.13 \mathrm{~Hz}, 2 \mathrm{H}), 6.92(\mathrm{~d}, J=9.11$

$\mathrm{Hz}, 2 \mathrm{H}), 7.03(\mathrm{~d}, J=6.50 \mathrm{~Hz}, 2 \mathrm{H}), 7.13(\mathrm{~d}, J=8.30 \mathrm{~Hz}, 1 \mathrm{H}), 7.16-7.22(\mathrm{~m}, 5 \mathrm{H}) \mathrm{ppm} .{ }^{13} \mathrm{C} \mathrm{NMR}$ $\left(125 \mathrm{MHz}, \mathrm{CDCl}_{3}\right): \delta 26.57,35.80,37.66,55.70,60.67,71.00,74.88,80.82,114.88,116.32$, 127.45, 128.99, 129.41, 134.91, 150.44, 154.64, 173.72, 186.30 ppm. IR $\left(\mathrm{CHCl}_{3}\right): 3499,2965$, $1704,1507,1367,1324,1045,827,702 \mathrm{~cm}^{-1} \cdot[\alpha]^{25}=+76\left(c 1.50, \mathrm{CHCl}_{3}\right)$. ESI HRMS for $\mathrm{C}_{24} \mathrm{H}_{29} \mathrm{NO}_{5} \mathrm{~S}$ : calc'd $\left(\mathrm{M}+\mathrm{H}^{+}\right)$444.1846, found 444.1832 .

\subsection{9. $\quad(2 S, 3 R)-4-B e n z y l-3-[(3-h y d r o x y-2-(p-m e t h o x y p h e n o x y)-5-m e t h y l h e x a n o y l)]$ oxazolidine-2-thione (12i).}

The title product was purified by flash column chromatography (hexanes: EtOAc, 75:25) to yield $0.567 \mathrm{~g}(91 \%)$ of the title compound as a mixture of diastereomers as an orange oil at $25^{\circ} \mathrm{C}$. By Method B, $0.590 \mathrm{~g}(1.33 \mathrm{mmol}, 95 \%)$ of white crystals were collected. Melting point: 49-51 ${ }^{\circ} \mathrm{C} .{ }^{1} \mathrm{H} \mathrm{NMR}\left(400 \mathrm{MHz}, \mathrm{CDCl}_{3}\right): 0.93(\mathrm{~d}, J=6.6 \mathrm{~Hz}, 3 \mathrm{H}), 0.97(\mathrm{~d}, J=6.6 \mathrm{~Hz}, 3 \mathrm{H}), 1.47-$ $1.54(\mathrm{~m}, 1 \mathrm{H}), 1.73-1.92(\mathrm{~m}, 2 \mathrm{H}), 2.12(\mathrm{~d}, J=11.0 \mathrm{~Hz}, 1 \mathrm{H}), 2.79(\mathrm{dd}, J=10.0,3.3 \mathrm{~Hz}, 1 \mathrm{H}), 3.26$ (dd, $J=10.0 \mathrm{~Hz}, 3.1 \mathrm{~Hz}, 1 \mathrm{H}), 3.77(\mathrm{~s}, 3 \mathrm{H}), 4.29-4.41(\mathrm{~m}, 3 \mathrm{H}), 4.88-4.94(\mathrm{~m}, 1 \mathrm{H}), 6.84-6.88(\mathrm{~m}$, $3 \mathrm{H}), 6.90-6.94(\mathrm{~m}, 2 \mathrm{H}), 7.15-7.17(\mathrm{~m}, 2 \mathrm{H}), 7.27-7.33(\mathrm{~m}, 2 \mathrm{H}) .{ }^{13} \mathrm{C}$ NMR (100 MHz, $\left.\mathrm{CDCl}_{3}\right): \delta$ $21.98,23.66,24.62,37.37,43.16,55.71,60.94,70.47,71.23,79.14,114.89,116.40,127.50$, 129.00, 129.49, 134.92, 151.54, 154.70, 170.63, 185.42. IR (neat): $3420,1729,1474,1444$, 1366, 1326, 1038, 126, 752, $702 \mathrm{~cm}^{-1} \cdot[\alpha]^{23}{ }_{\mathrm{D}}=+9.43\left(c 1.10, \mathrm{CHCl}_{3}\right)$. ESI HRMS for $\mathrm{C}_{24} \mathrm{H}_{29} \mathrm{NO}_{5} \mathrm{~S}:$ calc'd $\left(\mathrm{M}+\mathrm{H}^{+}\right) 444.1841$, found 444.1845 .

\subsection{Methyl 3-hydroxy-2-(p-methoxyphenoxy)-3-phenylpropanoate (13)}


In a $500 \mathrm{~mL}$, flame dried, nitrogen purged round bottom flask equipped with a magnetic stir bar was added imidazole $(2.316 \mathrm{~g}, 34.0 \mathrm{mmol}, 3$ equiv), anhydrous methanol (30 mL) and THF (20 mL). Compound 12a (4.602g, 9.94 mmol, 1 equiv) was then added and allowed to stir overnight. The $\mathrm{MeOH}$ was removed via rotary evaporation and the crude product was then extracted with $\mathrm{CH}_{2} \mathrm{Cl}_{2}(80 \mathrm{~mL})$ and sequentially treated with $1 \mathrm{M} \mathrm{HCl}(35 \mathrm{~mL})$ and brine (35 $\mathrm{mL}$ ). The solvent was removed by rotary evaporation to yield a viscous oil. This product was then purified by flash column chromatography (hexanes: EtOAc, 75:25) to yield a viscous oil (2.613 g, $8.64 \mathrm{mmol}, 87 \%) .{ }^{1} \mathrm{H}$ NMR (500 MHz, $\left.\mathrm{CDCl}_{3}\right): \delta 2.99(\mathrm{~s}, 1 \mathrm{H}), 3.54(\mathrm{~s}, 3 \mathrm{H}), 3.65$ (s, $3 \mathrm{H}), 4.56(\mathrm{~d}, J=5.3 \mathrm{~Hz}, 1 \mathrm{H}), 5.07(\mathrm{~d}, J=5.3 \mathrm{~Hz}, 1 \mathrm{H}), 6.68-6.72(\mathrm{~m}, 4 \mathrm{H}), 7.22-7.30(\mathrm{~m}, 3 \mathrm{H})$, 7.33-7.35 (m, 2H) ppm. ${ }^{13} \mathrm{C}$ NMR: $\delta 52.25,55.64,74.84,83.10,114.74,117.14,126.61,128.41$, 128.46, 138.74, 151.75, 155.03, 170.12 ppm. IR: 3569, 2964, 1748, 1507, 1393, 1052, 828, 701 $\mathrm{cm}^{-1} \cdot[\alpha]_{\mathrm{D}}^{23}=+146\left(c 0.50, \mathrm{CHCl}_{3}\right)$.

\section{Acknowledgements}

The authors acknowledge Zachary Lawton and Prof. C. Mulligan for their technical assistance in the collection of ESI-HRMS data. Structural elucidations were made with assistance from high resolution MS instrumentation acquired through support by the National Science Foundation MRI Program under Grant No. CHE 1337497.

\section{References}


1. (a) Evans, D. A.; Bender, S. L.; Morris, J. J. Am. Chem. Soc. 1988, 110, 2506-2526. (b) Keck, G. E.; Palani, A.; McHardy, S. F. J. Org. Chem., 1994, 59, 3113-3122. (c) Jones, T. K.; Reamer, R. A.; Desmond, R.; Mills, S. G. J. Am. Chem. Soc.1990, 112, 2998-3017.

2. (a) Crimmins, M. T.; Choy, A. L. J. Am. Chem. Soc. 1999, 121, 5653-5660. (b) Crimmins, M. T.; She, J. J. Am. Chem. Soc. 2004, 126, 12790-12791. (c) Crimmins, M. T. Ellis, J. M. J. Org. Chem. 2008, 73, 1649-1660.

3. Hulme, A. N; Rosser, E. M. Org. Lett. 2002, 4, 265-267. For the lesser used $\mathrm{N}_{3}$-methoxy acetyloxazolidinone, please see: (a) Crimmins, M. T.; Christie, H. S.; Chaudhary, K.; Long, A. J. Am. Chem. Soc. 2005, 127, 13810-13812. (b) Andrus, M. B.; Meredith, E. L.; Hicken, E. J.; Simmons, B. L.; Glancey, R. R.; Ma, W. J. Org. Chem. 2003, 68, 81628169.

4. Davies, S. G.; Nicholson, R. L.; Smith, A. D. Org. Biomol. Chem. 2004, 2, 3385-3400.

5. Owen, R. M.; Roush, W. R. Org. Lett. 2005, 7, 3941-3944.

6. Stallforth, P.; Adibekian, A.; Seeberger, P. H. Org. Lett. 2008, 10, 1573-1576.

7. (a) Crimmins, M. T.; Shamszad, M. Org. Lett. 2007, 9, 149-152. (b) Guz, N. R.; Phillips, A. J. Org. Lett. 2002, 4, 2253-2256. (c) Crimmins, M. T.; King, B. W.; Tabet, E. A.; Chaudhary, K.; J. Org. Chem. 2001, 66, 894-902. (d) Crimmins, M. T.; King, B. W.; Tabet, E. A. J. Am. Chem. Soc. 1997, 119, 7883-7884. (e) Crimmins, M. T. Ellis, J. M. J. Org. Chem. 2008, 73, 1649-1660. (f) Crimmins, M. T. Ellis, J. M. J. Am. Chem. Soc. 2005, 127, 17200-17201. (g) Crimmins, M. T.; Long, A. Org. Lett. 2005, 7, 4157-4160. (h) Crimmins, M. T.; McDougall, P. J. Org. Lett. 2003, 5, 591-594.

8. Baiget, J.; Caba, M.; Gálvez, E.; Romea, P.; Urpí, F.; Font-Bardia, M. J. Org. Chem. 2012, 77, 8809-8814. 
9. Giampietro, N. C.; Kampf, J. W.; Wolfe, J. P. J. Am. Chem. Soc. 2009, 131, 1255612557.

10. Fanjul, S.; Hulme, A. N. J. Org. Chem. 2008, 73, 9788-9791

11. (a) Andrus, M. B.; Meredith, E. L.; Hicken, E. J.; Simmons, B. L.; Glancey, R.; Ma, W. J. Org. Chem. 2003, 68, pp 8162-8169. (b) Andrus, M. B.; Meredith, E. L.; Soma Sekhar, B. B. V. Org. Lett. 2001, 3, pp 259-262. (c) Andrus, M. B.; Soma Sekhar, B. B. V.; Meredith, E. L.; Dalley, N. K. Org. Lett. 2000, 2, pp 3035-3037.

12. (a) Pearson, W. H.; Cheng, M. C. J. Org. Chem. 1987, 52, 3176-3178. (b) Pearson, W. H.; Cheng, M. C. J. Org. Chem., 1986, 51, pp 3746-3748.

13. (a) Wuts, P. G. M.; Greene, T. W. Protecting Groups in Organic Synthesis, $4^{\text {th }}$ Ed., John Wiley \& Sons, Inc. 2007.

14. (a) Yadav, J. S.; Dutta, P. J. Org. Chem. 2016, 81, 1786-1797. (b) Liu, Q.; An, C.; TenDyke, K.; Cheng, H.; Shen, Y. Y.; Hoye, A. T. Smith III, A. B. J. Org. Chem. 2016, 81, 1930-1942. (c)

15. (a) Castelli, R.; Overkleeft, H. S.; van der Marel, G. A.; Codee, J. D. C. Org. Lett. 2013, 15, 2270-2273. (b) Iacobucci, S.; Filippova, N.; d'Alarcao, M. Carbohydrate Res. 1995, 277, 321-325. (c) Jacob III, P.; Callery, P. S.; Shulgin, A. T.; Castagnoli, Jr., N. J. Org. Chem. 1976, 41, 3627-3629.

16. Vaughn, J. F.; Hitchcock, S. R. Tetrahedron: Asymm. 2004, 15, 3449-3455.

17. (a) Wu, Y.; Y. Y.-Q.; Hu, Q. J. Org. Chem. 2004, 69, 3990-3992. (b) Andrade, C. K. Z.; Rocha, R. O.; Vercillo, O. E.; Silva, W. A.; Matos, R. A. F. SynLett 2003, 2351-2352.

18. Crimmins and coworkers had developed a reaction protocol employing (-)-sparteine. Please see Crimmins, M. T.; She, J. SynLett 2004, 1371-1374. Our initial results with (-)- 
sparteine were not successful. These initial efforts were not optimized due to the uncertain availability and increasing cost of (-)-sparteine as a stoichiometric reagent. 


\section{Graphical Abstract}

for

\section{syn-Diastereoselective glycolate aldol addition reactions of}

\section{an $N(3)$-(p-methoxyphenoxy)acetyloxazolidine-2-thione}

Craig Haynes, Cassie A. Goodman, Juandah Bruce, Sarah C. Genin,

Brad Austermeuhle, Victor L. Leong, Austin R. Leise, Robert Larson,

Christopher G. Hamaker and Shawn R. Hitchcock*

Department of Chemistry, Illinois State University, Normal, IL 61790-4160
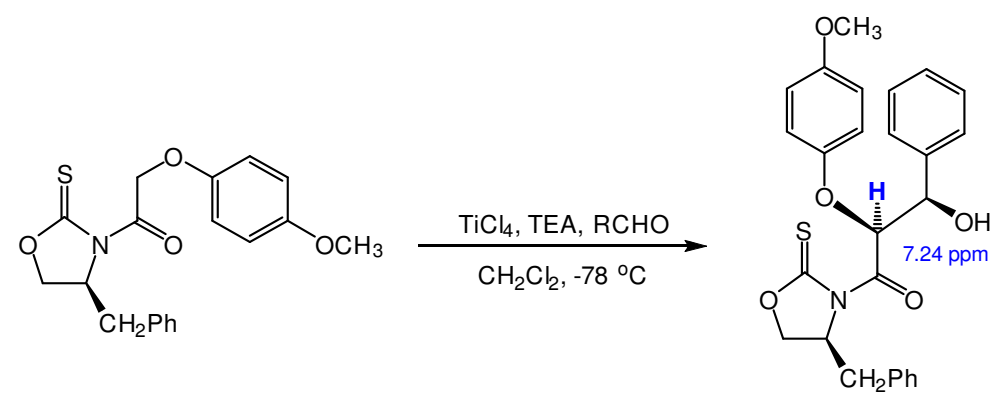